\title{
Sorghum: A Multipurpose Bioenergy Crop
}

\author{
P. Srinivas Rao, * K.S. Vinutha, G.S. Anil Kumar, T. Chiranjeevi, \\ A. Uma, Pankaj Lal, R. S. Prakasham, H.P. Singh, R. Sreenivasa \\ Rao, Surinder Chopra, and Shibu Jose
}

\begin{abstract}
Bioethanol and biodiesel produced from renewable energy sources are gaining importance in light of volatile fossil fuel prices, depleting oil reserves, and increasing greenhouse effects associated with the use of fossil fuels. Among several alternative renewable energy sources, energy derived from plant biomass is found to be promising and sustainable. Sorghum [Sorghum bicolor (L.) Moench] is a resilient dryland cereal crop with wide adaptation having high water, nutrient, and radiation use efficiencies. This crop is expected to enhance food, feed, fodder, and fuel security. Sweet sorghum is similar to grain sorghum but has the ability to accumulate sugars in the stalks without much reduction in grain production. Hence, it is used as a first-generation biofuel feedstock, where the grain and stalk sugars can be used for producing bioenergy, while energy sorghum or biomass sorghum is increasingly viewed as a potential feedstock for lignocellulosic biofuel production. Although the commercial use of sweet sorghum for bioethanol production has been demonstrated in China and India, the viability of large-scale lignocellulosic conversion of sorghum biomass to biofuels is yet to be demonstrated. This chapter dwells on sorghum feedstock characteristics, biofuel production models, sustainability indicators, and commercialization.
\end{abstract}

Sorghum (Sorghum bicolor (L.) Moench) originated in the Sahel region of Africa (Legwaila et al., 2003), is adapted to tropical and temperate cropping systems, and is one of the five most cultivated crop species globally. It is used for food, feed, fuel, fiber, brewing, and construction purposes (Srinivasarao et al., 2015). It is efficient in converting $\mathrm{CO}_{2}$ into sugar (Schaffert and Gourley, 1982) and highly productive with tolerance to drought, water logging, and salinity (Almodares et

\begin{abstract}
Abbreviations: bmr, brown midrib; CU, centralized unit; DCU, decentralized unit; GHG, greenhouse gas; IRR, internal rates of return; LCA, life cycle assessment; SWOT, strengthweakness-opportunities-threat.

P. Srinivas Rao, K.S. Vinutha (vinuthaks.mysore@gmail.com), and G.S.A. Kumar (anilkumargpb99@ gmail.com), ICRISAT, Research Program on Dryland Cereals, Patancheru 502 324, India; T. Chiranjeevi (chiranjeevi.tulluri@gmail.com), and A. Uma, Jawaharlal Nehru Technological Univ., Dep. of Biotechnology, Hyderabad, India; P. Lal, Montclair State Univ., NJ (lalp@mail.montclair.edu); R.S. Prakasham, CSIR-Indian Inst. of Chemical Technology (IICT), Hyderabad 500007, India (prakashamr@ gmail.com); H.P. Singh, Fort Valley State Univ., GA (singhh@fvsu.edu); R. Sreenivasa Rao, Inst. of Biological Environmental and Rural Sciences (IBERS), Aberystwyth Univ., Gogerddan, Aberystwyth, Ceredigion, SY23 3EE, UK (rsr@aber.ac.uk); S. Chopra, Dep. of Plant Sciences, Penn State Univ., PA (sic3@psu.edu); and S. Jose, Center for Agroforestry, Univ. of Missouri, Columbia, MO (joses@missouri. edu). *Corresponding author (psrao@ufl.edu; psrao72@gmail.com). P. Srinivas Rao and K.S. Vinutha contributed equally to this work.
\end{abstract}

doi:10.2134/agronmonogr58.2014.0074

(c) ASA and CSSA, 5585 Guilford Road, Madison, WI 53711, USA. Sorghum: State of the Art and Future Perspectives, Ignacio Ciampitti and Vara Prasad, editors. Agronomy Monograph 58. 
al., 2008; Promkhambut et al., 2010). It is commonly grown where maize (Zea mays L.) and other major cereals are less well adapted, especially because of soil and climate constraints. The plant height ranges from 1.5 to $3.0 \mathrm{~m}$ (energy sorghum up to $6.5 \mathrm{~m}$ ); the optimum temperature for growth and photosynthesis is 32 to $34^{\circ} \mathrm{C}$ with a day length of 10 to $14 \mathrm{~h}$; the optimum rainfall is 550 to $800 \mathrm{~mm}$ (Srinivasarao et al., 2009). With the availability of photoinsensitive genotypes, this crop is becoming popular for meeting food and fuel requirements. Hence, this review discusses the suitability of sorghum as an alternative feedstock for biofuel production and its value-chain sustainability. In the United States, sweet sorghum is primarily grown in the southeastern states and is usually planted between May and July. It was introduced to the United States in 1853 and cultivated for the sweet syrup extracted from its stalk and grain but is also used as a livestock grain and forage crop in the Great Plains states (Dweikat et al., 2012; National Sweet Sorghum Producers and Processors Association, 2015).

\section{Types of Sorghum}

Sorghum is a versatile species that is produced as a source of grain and forage. Based on the origin of the crop, five basic cultivated races reflect regional adaptation of sorghum, while 10 intermediate races and six spontaneous races were identified (House, 1985; Harlan and de Wet, 1972, 1971). However, genetic manipulation of grain sorghum has resulted in the development of improved cultivars (Prakasham et al., 2014) of sweet (sugars), low-lignin (bmr), and energy (biomass) sorghums. Please refer the Supplemental Material for further details.

\section{Grain Sorghum}

Grain sorghum contains either two or three dwarfing genes (Brown et al., 2008) and are 0.61 to $1.22 \mathrm{~m}$ tall. While there are several grain sorghum groups, most current grain sorghum hybrids have been developed by crossing Milo with Kafir. Other groups include Hegari, Feterita, Durra, Shallu, and Kaoliang. The grain is freethreshing, as the lemma and palea are removed during combining. The seed color is variable with yellow, white, brown, and mixed classes in the grain standards. Brown-seeded types are high in tannins, which lowers the palatability. High starch content, rapid liquefaction, and low viscosity during liquefaction was desired in the grain sorghum for ethanol production. Major factors adversely affecting the bioconversion process of sorghum are tannin content, low protein digestibility, and high mash viscosity.

\section{Sweet Sorghum}

Sweet sorghum, similar to grain sorghum except for the sugar and juice-rich stalk, has been grown for syrup and fodder for many centuries. Sweet sorghum is considered to be a potential bioethanol feedstock in addition to meeting food, feed, fodder, fuel, and fiber demands. Some sweet sorghum lines attain juice yields of $78 \%$ of total plant biomass, containing 15 to $23 \%$ soluble fermentable sugar (Srinivasarao et al., 2009; Vinutha et al., 2014). The sugar is composed mainly of sucrose (70-80\%), fructose, and glucose. Most of the sugars are uniformly distributed in the stalk with about $2 \%$ in the leaves and inflorescences (Vietor and Miller, 1990), making the crop particularly amenable to direct fermentable sugar extraction. Sweet sorghum, with its structural sugars $\mathrm{C}_{5}$ and $\mathrm{C}_{6}$, obtained from cellulose and 
hemicellulose components of the bagasse could be used both for first- and second-generation biofuel. Ethanol is produced from sweet sorghum juice and is most similar to the molasses-based ethanol production process.

\section{Forage Sorghum}

Forage sorghum is used primarily as silage for livestock. It is harvested at the soft dough stage of development and ensiled. It contains 52 to $65 \%$ dry matter digestibility, 8 to $12 \%$ crude protein, 60 to $75 \%$ neutral detergent fiber, and 34 to $40 \%$ acid detergent fiber. Ensiled grain has a digestibility of about $90 \%$. The sorghum silage contains less grain and is higher in fiber than corn silage. To obtain the optimum rate of gain for most livestock, sorghum silage must be supplemented with protein, minerals, and vitamins. Young plants contain an alkaloid, which releases hydrocyanic acid or prussic acid when hydrolyzed. This can be toxic to livestock; therefore, livestock feeding needs to be avoided during this stage. When the crop is cut and field-cured, the hydrocyanic acid dissipates. When it is ensiled, the hydrocyanic acid degrades slowly over 2 to $3 \mathrm{wk}$.

\section{Brown Midrib Sorghum}

Brown midrib $(b m r)$ mutations are novel mutants in sorghum that usually contain less lignin ( $<6 \%$ in some lines) because of modifications in the phenylproponoid pathway (Saballos et al., 2008). In sorghum, bmr mutants were first developed at Purdue University via chemical mutagenesis, and the altered lignin content was characterized by brown vascular tissue (Porter et al., 1978). Introgression of several $\mathrm{bmr}$ alleles into high biomass and stay green lines was performed, and most of the bmr mutants resulted in increased yields of fermentable sugars followed by enzymatic saccharification albeit with varied background effects. Alleles of $b m r 12, b m r 18$, $b m r 26$, and bmr6 have been characterized at the molecular level (Bout and Vermerris., 2003; Saballos et al., 2009; Sattler et al., 2010). Allelic genes bmr12 and bmr18 decrease caffeic acid $O$-methyltransferase activity and bmr6 has been linked to a decrease in cinnamyl alcohol dehydrogenase activity (Oliver et al., 2005).

\section{Energy Sorghum}

Energy sorghum is a forage sorghum bred for high biomass production. Elucidation of the flowering time gene regulatory network and identification of complementary alleles for photoperiod sensitivity enabled large-scale generation of energy sorghum hybrids for testing and commercial use in biofuel production. Energy sorghum hybrids with long vegetative growth phases were found to accumulate more than twice as much biomass as grain sorghum, owing to extended growing seasons, greater light interception, and higher radiation use efficiency. High biomass yield, efficient nitrogen recycling, and preferential accumulation of stem biomass with low nitrogen content contributed to energy sorghum's elevated nitrogen use efficiency. Several biomass sorghum hybrids have been developed and improved for the production of lignocellulosic sugar and as starch feedstock. Biomass yields vary between 15 and $25 \mathrm{t} \mathrm{ha}^{-1}$ but have been reported to be as high as $40 \mathrm{t} \mathrm{ha}^{-1}$ (Packer and Rooney, 2014).

\section{Biomass Composition}

The biomass composition performed with Fibertherm (C. Gerhardt Analytical Systems) has yielded a ballpark figure of the various components like cellulose, 
hemicellulose, lignin, and ash. The analysis was performed across grain, forage, sweet, brown midrib, and energy sorghum. The samples were collected from experiments conducted in the post-rainy season, 2013 to 2014 at ICRISAT. The biomass samples were dried, ground, and sieved $(0.2 \mathrm{~mm})$ to obtain uniform sized samples. The hemicellulose content ranged from 22.37 to $30.15 \%$, cellulose from 34.32 to $39.16 \%$, lignin from 4.63 to $16.82 \%$, and ash from 1.83 to $3.2 \%$. The hemicellulose content of $b m r$ and energy sorghum are 29.2 and 30.15\%, whereas the lignin content is lowest in $b m r$ sorghum at $4.63 \%$, and the energy sorghum has a lignin of $10.25 \%$. Explicitly, the cellulose content is reported higher in bmr sorghum (39.16\%) than in energy sorghum (37.55\%) (Fig. 1).

Sweet sorghum plays a dual role in the bioethanol value chain. Once the juice is extracted for fermentation, the bagasse remaining can be used for the lignocellulosic conversion, thus increasing the ethanol yield and achieving complete consumption of raw material. The sweet sorghum has $24.87,34.32$, and $8.39 \%$ of hemicellulose, cellulose, and lignin, respectively. Thus, $b m r$ and energy sorghum with high potential biomass yield can be used for bioethanol production. Sweet sorghum can also be promoted as a complementary feedstock in the sugar mill areas where sugarcane (Saccharum officinarum L.) is the popular feedstock (Srinivasarao et al., 2012).

\section{Bioethanol from Sorghum: Current Scenario}

Sweet sorghum is valued as one of the promising nonfood feedstocks for bioethanol production. Bioethanol from sweet sorghum is regarded as a 1.5-generation biofuel, that is, derived from a food crop part not used for consumption (Li et al., 2013; Wang et al., 2014a). The fuel produced from the sweet sorghum juice is relatively clean with a low production cost. An ethanol yield based on total sugar of
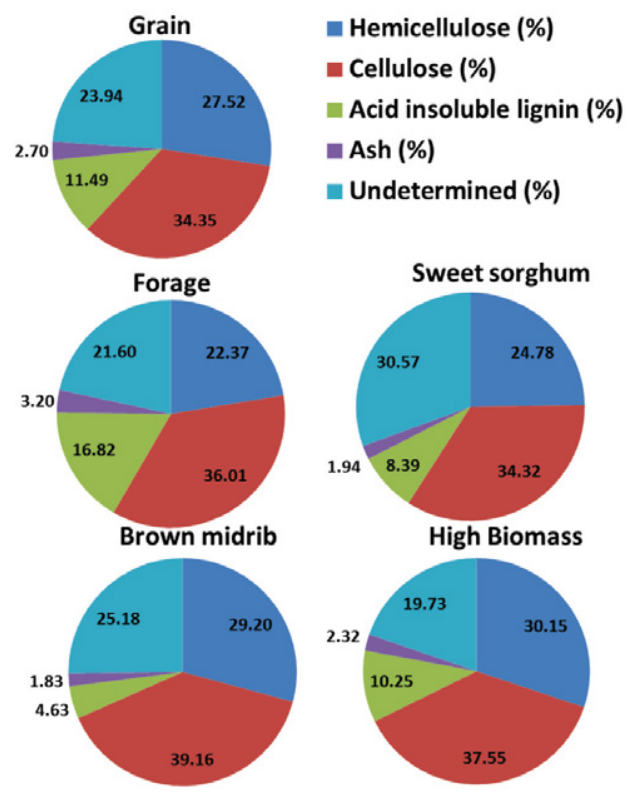

Fig. 1. Biomass composition of different types of sorghum analyzed in the Fibertherm. 
$480 \mathrm{~g} \mathrm{~kg}^{-1}$ was obtained after $24 \mathrm{~h}$ of fermentation using a mixed culture of organisms. This shows the potential for producing as much as $0.252 \mathrm{~m}^{3} \mathrm{t}^{-1}$ or $33 \mathrm{~m}^{3} \mathrm{ha}^{-1}$ ethanol using only the lignocellulose part of the sweet sorghum stalks. This yield is high enough to make the process economically attractive (Marx et al., 2014). The average ethanol productivity was $\sim 220 \mathrm{~g}$ ethanol kg-1 of original dry stem of sweet sorghum, equivalent to $2465 \mathrm{~L}$ ethanol ha-1 (Cifuentes et al., 2014). It can be a supplementary feedstock to the sugar mills operating with the distilleries in the off season (2 mo), development of average revenue of US\$3 million for a crushing rate of $6500 \mathrm{t} \mathrm{d}^{-1}$ can be achieved in dryland situations. Several studies have highlighted the potential of sweet sorghum for ethanol production (Srinivasarao et al., 2009), and it was reported as a viable feedstock for electricity production (Cutz et al., 2013).

Energy sorghums are being developed solely as an energy crop. Because of its height $(3-6 \mathrm{~m})$ and a long vegetative growth phase, it has with the advantage of greater light interception and higher radiation use efficiency. The biomass accumulated in energy sorghum is double that accumulated in grain sorghum. Theoretical ethanol yields of potential lines of energy sorghum are $\sim 25 \%$ higher than the current yields. Biomass sorghums have the potential to produce high tonnages of $\mathrm{C}_{5}$ and $\mathrm{C}_{6}$ sugars and lignin. The biomass yield varies between 15 and $25 \mathrm{t} \mathrm{ha}^{-1}$, and as high as $40 \mathrm{t} \mathrm{ha}^{-1}$ has been reported (Packer and Rooney, 2014). The yield of energy sorghum hybrids ranged from 27.2 to $32.4 \mathrm{tha}^{-1}$ with a wide variety of parental sources (Packer and Rooney, 2014).

The main dispute on second-generation bioethanol is the cost for the establishment of the enzymatic conversion of biomass to bioethanol (Giarola et al., 2012). The major hurdle in second-generation biofuel production is the intricate conversion of biomass to biofuel, pretreatment for removal of lignin, and the enzymes used for saccharification. During the conversion process of biomass to biofuel, the presence of lignin is not a hindrance for biohydrogen production by anaerobic fermentation. However, in the enzymatic conversion process to bioethanol, the effect of lignin is very significant (Prakasham et al., 2012). Hence, to reduce the pretreatment cost, conventional or mutational breeding methods can be used for developing lines possessing low lignin. In sorghum, bmr mutants are promising because of the defective genes in the phenylproponoid pathway resulting lower lignin accumulation in secondary cell walls $(<6 \%)$. Deployment of introgression techniques for $b m r$ genes into sweet or energy sorghum to develop biomass with low lignin content is being explored widely. These new introgressed lines are expected to catalyze the development of biofuel industries and make the conversion economically viable. The biomass yield and quality are of prime concern for the viability of commercial biofuel industries.

\section{Sorghum as Raw Material for Industrial Products}

\section{Crystal Sugar}

Sweet sorghum juice is a rich source of sucrose $(85 \%$ sucrose, $9 \%$ glucose, and $6 \%$ fructose) that could effectively be used for the production of crystalline white sugar (Woods, 2000). However, the presence of several inorganic components and impurities need to be eliminated before starting crystalline sugar production. The juice is clarified with liming followed by saturation with carbonation to capture the impurities through precipitation of the lime milk. The thin purified 
juice obtained after the filtration process is thickened in a multieffect evaporator. The thin juice is diluted with water during extraction and purification and then passes to the evaporating station with an average sugar content of $15 \%$. The thick juice leaving the evaporator contains $\sim 70 \%$ sugar (Kangama and Rumei, 2005). White crystalline sugar production appears to be limited to lab scale but has not been commercialized anywhere.

\section{Lipids}

The sorghum bagasse remaining after juice extraction can be an excellent source for the production of various valuable bioproducts such as lipids produced by microbial fermentation. Some of the microbial candidates are referred to as oleaginous because of their high cellular lipid content $(>20 \% \mathrm{w} / \mathrm{w})$ accumulation (Ratledge and Wynn, 2002). Among different species, Cryptococcus curvatus is one of the most efficient candidates for microbial fermentation, which can accumulate storage lipids up to $60 \%$ of dry cell weight (Meng et al., 2009). This microbe can grow on a wide range of mono- and disaccharides (Glatz et al., 1984). Since sorghum straw is a good source for cellulose and hemicellulose sugars, it can be used for the production of single-cell oil.

\section{Biodegradable Plastics}

Biodegradable plastics could be made using lignin derived from sorghum biomass (Ashori, 2008). Lignin is a by-product of bioethanol production. Furthermore, sorghum cellulose fiber can be used for reinforcement of thermoplastic materials such as biodegradable wood composites (Ashori, 2008). Sorghum fiber, the residue that is obtained after pretreatment, can be used for the reinforcement of biodegradable composites. The term wood composite refers to any composite that contains plant fibers (wood and nonwood based) and thermosets or thermoplastics (Ashori, 2008). Wood composites are potential green materials, as nontoxic chemicals are employed in their manufacture. Furthermore, the dimensional stability of these materials is more advanced than the traditional wood products. The sorghum fibers can be mixed with polylactic acid, and the resulting composite can be used as a completely biodegradable matrix (Satyanarayana et al., 2009).

\section{Beverage and Dietary Products}

Sorghum is the primary food grain in parts of India and Africa, where it is mainly used in making bread, porridges, and opaque alcoholic beers (dregs) (Rooney, 1967; Serna-Saldivar et al., 1988; Bello et al., 1990; Mohammed et al., 1993). Though sorghum has been used for centuries to brew traditional (opaque) beer in Africa (Faparusi, 1970), it has only been recently that sorghum beer brewing has been established into a major industry. The types of beers differ from European (lager) in that lactic acid fermentation also occurs during sorghum beer processing. The sorghum alcoholic drink is consumed while still fermenting and contains large amounts of insoluble materials (Serna-Saldivar et al., 1988), which are mainly starch fragments and dextrins that are not digested during mashing and fermentation (Glennie and Wight, 1986). Ting is a spontaneously fermented sorghum food that is popular for its sour taste and unique flavor. Insight of the microbial diversity and population dynamics during sorghum fermentations is an essential component of the development of starter cultures for commercial production of ting. 
Sorghum grains are gluten free and with a high potential to be used as an alternative to wheat flour for the celiac sprue market (Liu et al., 2012). In fact, sorghum grains are minor cereals that form the staple food for a large segment of the population in India and Africa. Use of sorghum for food is still mostly confined to the traditional consumers and populations in lower economic strata, partly because of nonavailability of these grains in ready-to-eat forms. Sorghum is not only nutritionally comparable but is also superior to major cereals with respect to protein, energy, vitamins, and minerals (McKevith, 2004). Moreover, it is rich in dietary fiber, phytochemicals, and micronutrients (Chakraborty et al., 2011).

\section{Biofuel}

The production of ethanol from the sugar-rich sweet juice is a common process and has been commercialized in Brazil for the past four decades. The alcohol concentration rises from 6 to $7 \%(\mathrm{v} / \mathrm{v})$ in the last fermentation step where the temperature is kept between 33 and $35^{\circ} \mathrm{C}$. Yeast cream is separated by centrifuges into holding tanks, and clarified juice from the separators is fed into the fermentation buffer tank. Ethanol is then recovered from the fermentation broth by distillation and dehydration. Anhydrous ethanol is realized by passing through a distillation column and a rectification column coupled with vapor-phase molecular sieves in which a mixture of nearly azeotropic water and ethanol is purified. The ethanol yield is 50 to $65 \mathrm{~L} \mathrm{t}^{-1}$ from the sweet juice process.

The major components of sorghum bagasse are cellulose, hemicellulose, and lignin. Thus, like any other lignocellulosic biomass, sorghum biomass can also be converted to fuel ethanol. For this purpose, the key elements involved are pretreatment and enzymatic saccharification to liberate fermentable sugars. Several pretreatment strategies have been reported including sulfuric acid, hydrochloric acid, phosphoric acid, steam, dilute ammonia hydroxide, ammonia fiber explosion, and hot water (Menon and Rao, 2012). However, a conclusion has not been reached on the best pretreatment technology for industrial-scale ethanol production because of the high cost of downstream processing of fermentable sugars, cellulase enzymes, etc. The produced fermentable sugars can also be used for the production of biohydrogen by using various microbial consortia (Prakasham et al., 2012). The fermenting microbial candidates for the production of various potential industrial commodities are furnished in Table 1.

\section{Paper Pulp}

After the extraction of juice sugars in conditions adaptable to the industrial scale, sweet sorghum bagasse can be used for manufacturing paper pulp. The quality of the pulp obtained is similar as regular softwood used for paper making. Research reports suggest that the sorghum pulp exhibits a degree of cohesion higher than $80 \%$; a low kappa number, indicating a good delignification; a high degree of polymerization; and exceptional physicomechanical properties. This allows the consideration of sweet sorghum as a major raw material for the paper industry in every region where it will be possible to grow it in association with sugarcane. These pulps can be used in sectors usually restricted to superior chemical pulps such as those obtained from softwood (Belayachi and Delmas, 1995). 
Table 1. Fermenting microbial organisms used for production of various products using sorghum biomass (Prakasham et al., 2014).

\begin{tabular}{|c|c|c|}
\hline Product & Microorganism & Reference \\
\hline Bioethanol & Saccharomyces cerevisiae & $\begin{array}{l}\text { Wu et al., 2010; Bridgers et al., 2011; } \\
\text { Ostovareh et al., } 2015\end{array}$ \\
\hline Acetone & Bacillus acetobutylicum & Cheng et al., 2008 \\
\hline Butanol & $\begin{array}{l}\text { Bacillus acetobutylicum, Clostridium } \\
\text { acetobutylicum }\end{array}$ & Cheng et al., 2008; Zhang et al., 2011 \\
\hline Biohydrogen & $\begin{array}{l}\text { Caldicellulosiruptor saccharolyticus, } \\
\text { Ruminococcus albus, Clostridia spp. }\end{array}$ & $\begin{array}{l}\text { Antonopoulou et al., 2008; Ntaikou et } \\
\text { al., 2010; Panagiotopoulos et al., 2010; } \\
\text { Saraphirom and Reungsang 2010; Prakasham } \\
\text { et al., } 2012\end{array}$ \\
\hline Lactic acid & $\begin{array}{l}\text { Lactobacillus delbruckii, L. paracasei, } L \text {. } \\
\text { plantarum }\end{array}$ & $\begin{array}{l}\text { Samuel et al., 1980; Richter and Berthold; } \\
\text { 1998; Hetényi et al., 2010; Yadav et al., } 2011\end{array}$ \\
\hline Lipids & $\begin{array}{l}\text { Chlorella protothecoides, Mortierella } \\
\text { isabellina, Cryptococcus curvatus, } \\
\text { Schizochytrium limacinum }\end{array}$ & $\begin{array}{l}\text { Economou et al., 2010; Gao et al., 2010; Liang } \\
\text { et al., 2010, } 2012\end{array}$ \\
\hline Methane & Ubiquitous microflora & $\begin{array}{l}\text { Jerger et al., 1987; Klimiuk et al., 2010; } \\
\text { Matsakas et al., } 2014\end{array}$ \\
\hline $\begin{array}{l}\text { Enzymes: } \\
\text { cellulases, } \\
\text { xylanases }\end{array}$ & Trichoderma spp., Aspergillus spp. & Uma, unpublished data, 2015 \\
\hline
\end{tabular}

\section{Biofuel Production Models}

\section{The Centralized and Decentralized Unit Ethanol Production Models}

The biofuel production value-chain model for sweet sorghum encompasses the stalk production, transportation, crushing, ethanol production, and thus blending with gasoline. In this section two primary models are examined for the success of the value-chain production model of sorghum feedstock bioethanol. The fundamental capabilities are compared for a centralized unit (CU) model and a decentralized unit (DCU) model in Table 2.

Table 2. Characteristics of centralized unit (CU) and decentralized unit (DCU) biofuel production models (Belum et al., 2013).

\begin{tabular}{|c|c|c|}
\hline Model & CU (Fig. 2) & DCU (Fig. 3) \\
\hline Description & $\begin{array}{l}\text { A constellation of villages closer to the } \\
\text { crushing units are aimed for the cultivation } \\
\text { of crops along with the transportation of } \\
\text { the sweet sorghum stalks to the crushing } \\
\text { units. In CU, the requirement of feedstock } \\
\text { for } 40 \mathrm{~kL} \mathrm{~d}^{-1} \text { is } 8000 \text { ha crop area } \mathrm{yr}^{-1} \text { for } \\
\text { two seasons for ethanol distillery. }\end{array}$ & $\begin{array}{l}\text { Involves the crushing of sweet sorghum } \\
\text { stalks, extracting and boiling the juice for } \\
\text { syrup production. The sweet sorghum } \\
\text { is managed by a farmers group or } \\
\text { microentrepreneurs under the DCU located } \\
\text { in the villages that are more than } 50 \mathrm{~km} \\
\text { distance from the distilleries. }\end{array}$ \\
\hline Advantages & $\begin{array}{l}\text { Supply of the sweet sorghum stalks } \\
\text { directly from the farmer's field to the } \\
\text { distillery takes little time, keeping the } \\
\text { transportation costs minimal. }\end{array}$ & $\begin{array}{l}\text { This model links farmers to input supply } \\
\text { agencies including credit or financial } \\
\text { institutions and output markets through } \\
\text { capacity building. This model also assures } \\
\text { links between the DCU and the distillery } \\
\text { with a buyback agreement for syrup supply } \\
\text { on a preagreed price. }\end{array}$ \\
\hline Disadvantages & $\begin{array}{l}\text { The farmer located more than } 50 \mathrm{~km} \\
\text { radius has to bear high charges for } \\
\text { transporting the feedstock. Delay in the } \\
\text { supply of the feedstock because of a } \\
\text { longer distance would further reduce the } \\
\text { sugar stalk weight and juice yield. During } \\
\text { postrainy cultivation season, it is difficult to } \\
\text { find } 4500 \text { ha land with irrigation facilities. }\end{array}$ & $\begin{array}{l}\text { For establishment of DCU, high initial } \\
\text { investment is required. For procuring small } \\
\text { quantities of syrup from DCU, assurance } \\
\text { has to be given by distilleries alone. For } \\
\text { industry payment, a schedule and price } \\
\text { fixation criterion is syrup. Payments to } \\
\text { farmers to be based on either stalk weight } \\
\text { or syrup quality. }\end{array}$ \\
\hline
\end{tabular}




\section{Sweet Sorghum Ethanol Value Chain:}

\section{A Strength-Weakness-Opportunities-Threat Analysis}

\section{of Centralized and Decentralized Unit Ethanol Production Models}

Ethanol production from sweet sorghum has emerged as an alternative to fossil fuels. Sweet sorghum stalks are converted into juice and fermented to produce bioethanol. Two pilot models are tested for conversion of sweet sorghum into bioethanol. In the CU model (Fig. 2), the stalks are supplied directly to the distillery, and in DCU model (Fig. 3), the stalks are processed into syrup at the village level and then transported to the CU model distillery for ethanol production. A

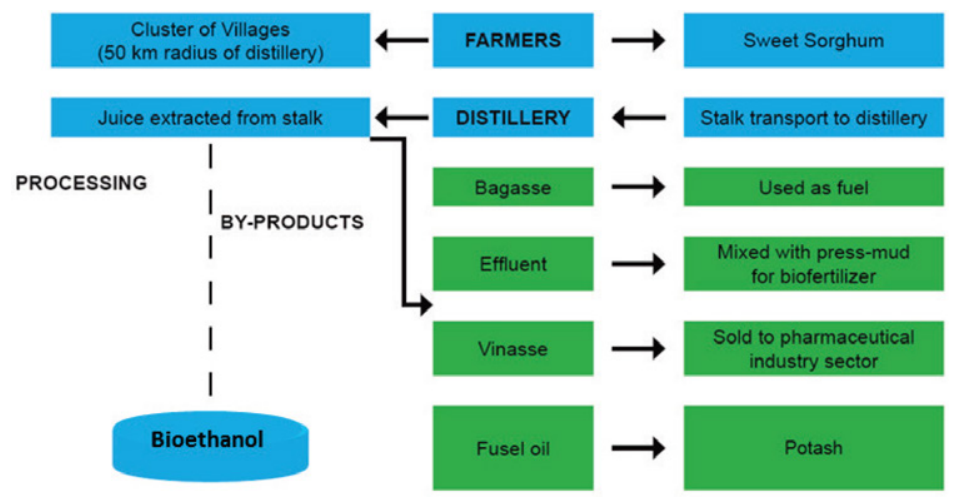

Fig. 2. Centralized unit of the sweet sorghum supply chain linking farmers to the distillery (Basavaraj et al., 2012).

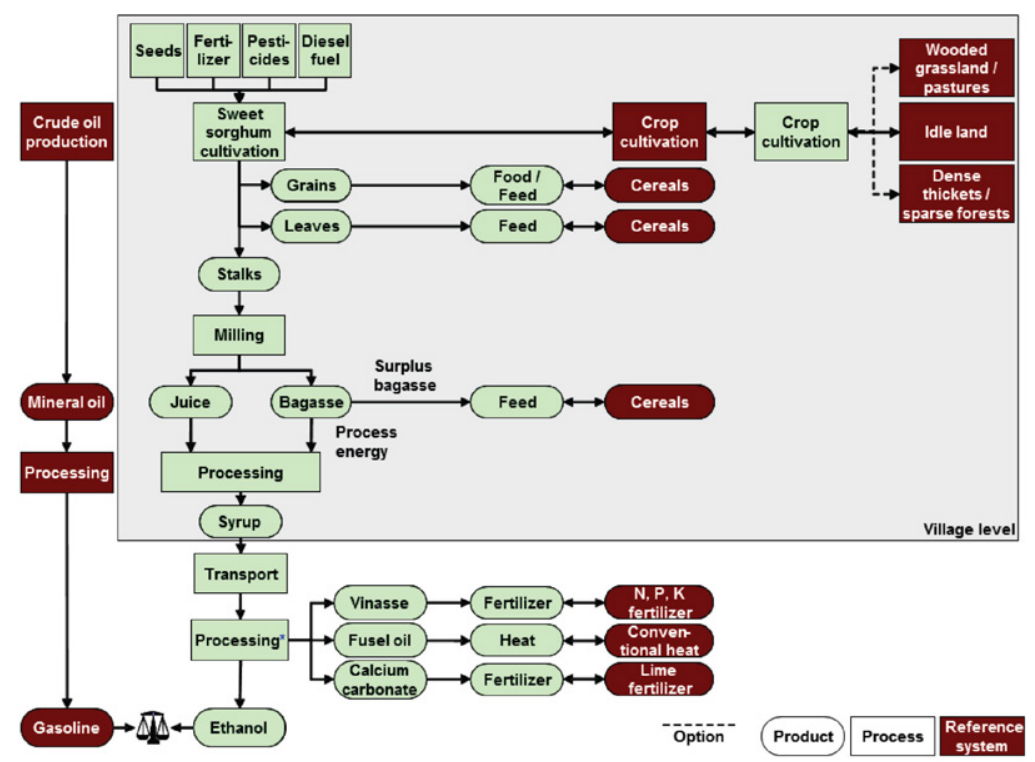

Fig. 3. Decentralized unit: A group of farmers or villages crush sweet sorghum stalks and produce syrup; the decentralized unit is linked with a centralized unit for ethanol production (Srinivasarao et al., 2013; Reinhardt and Cornelius, 2014). 
strength-weakness-opportunities-threat (SWOT) analysis was performed on both CU and DCU models. Several attempts were made to use sweet sorghum for ethanol production in a CU model by crushing stalks for juice production at industry level (Srinivasarao et al., 2013). Because of the restriction of the availability of raw materials for a shorter time period, along with difficulties in timely transporting the harvested material from the farmer's field to the distillery, this model could not take off. But, sweet sorghum to ethanol value chain in DCU was also proved to have a better outlook on the conversion of the juice to syrup and further to ethanol in the CU (Basavaraj et al., 2013; Belum et al., 2013). During the implementation of the aforementioned two models, a number of issues have emerged in using sweet sorghum as an alternative feedstock. Thus, the SWOT analysis was performed for both models (Table 3).

\section{Business Model for the Viability of Sweet Sorghum Decentralized Unit}

The Agri-Business Incubation program of ICRISAT, in partnership with National Agriculture Innovation Project, has considered various business models based on the viability of the various DCU models (Table 4).

Cost is the major impedance component for the DC unit. Various models have been developed to establish the crushing unit that will offset investments.

Table 3. The strength-weakness-opportunities-threat analysis performed on the two developed models, centralized unit (CU) and decentralized unit (DCU), for biofuel production from sorghum (Belum et al., 2013).

\begin{tabular}{|c|c|c|}
\hline Model & $\mathrm{CU}$ & DCU \\
\hline Strengths & $\begin{array}{l}\text { Targeted crop cultivation in the } \\
\text { vicinity of CU improves juice recovery } \\
\text { and minimizes the transportation cost } \\
\text { of the stalks to the CU. Crushes the } \\
\text { raw material in bulk quantities before } \\
\text { in-stalk fermentation sets in. }\end{array}$ & $\begin{array}{l}\text { Crushing of the stalks without delay resulting in } \\
\text { good quality juice yield. Reduces transportation } \\
\text { of feedstock. The by-product, such as bagasse, } \\
\text { can be used for livestock feed and as an organic } \\
\text { matter to enrich the soil. The produced syrup can } \\
\text { be stored as long as } 24 \text { mo before its conversion } \\
\text { to ethanol. }\end{array}$ \\
\hline Weaknesses & $\begin{array}{l}\text { The CU needs to be supplied } \\
\text { with raw material throughout the } \\
\text { year, which is neither feasible nor } \\
\text { economical for the agroprocessors } \\
\text { to run the processing unit to full } \\
\text { capacity based on a single feedstock. } \\
\text { Constraints for the availability of } \\
\text { required land to produce raw material } \\
\text { for whole year. }\end{array}$ & $\begin{array}{l}\text { Lack of coordination and implementation of } \\
\text { strategies. Broadcasting of information by way of } \\
\text { initial training programs or awareness camps is } \\
\text { expensive. Lack of management skills in operating } \\
\text { and handling DCU. The costs involved in the } \\
\text { establishment of DCU and further processing and } \\
\text { operating is very high. Incompetence of DCUs in } \\
\text { providing large quantities of syrup as raw material. }\end{array}$ \\
\hline Opportunities & $\begin{array}{l}\text { CU can enter into contractual } \\
\text { agreements with the small farmers } \\
\text { to overcome land constraints } \\
\text { by contract farming or buyback } \\
\text { agreements. Production activities } \\
\text { must be seen as a part of the whole } \\
\text { chain supply. Direct linkage of } \\
\text { farmers to the markets will provide a } \\
\text { long-term relationship between the } \\
\text { farmers and the stakeholders. }\end{array}$ & $\begin{array}{l}\text { Mechanize and standardize most of the } \\
\text { processing activities. It adds value for other } \\
\text { by-products that can be made available for } \\
\text { alternative markets. This model provides } \\
\text { opportunities for low-income group farmers } \\
\text { to become microlevel entrepreneurs through } \\
\text { establishment and management of DCU without } \\
\text { any dependence on the partners. This model also } \\
\text { makes possible the government's mandate of } \\
\text { blending ethanol with gasoline. }\end{array}$ \\
\hline Threats & $\begin{array}{l}\text { The government can strengthen the } \\
\text { efficiency of linkages by framing a } \\
\text { policy benefiting both the farmers } \\
\text { and the processors. It requires high } \\
\text { volumes of stalk and transportation } \\
\text { costs are high. }\end{array}$ & $\begin{array}{l}\text { DCU is hugely dependent on distilleries. The } \\
\text { cost of producing syrup is high, threatening } \\
\text { the feasibility of a DCU. Syrup production can } \\
\text { be affected due to labor. Lack of support from } \\
\text { the government in implementing policies that } \\
\text { would benefit the ethanol sector. A proper policy } \\
\text { alignment is required for the production of fuel } \\
\text { ethanol for the success of an ethanol program }\end{array}$ \\
\hline
\end{tabular}


Table 4. The five business models developed for the viability of sweet sorghum decentralized unit (DCU) (Belum et al., 2013).

\begin{tabular}{lll} 
Model parameters & Approach to business model & \multicolumn{1}{c}{ Model assumptions } \\
\hline 1. DCU as a standalone unit & Operated by individuals or group. & $\begin{array}{l}\text { Not sustainable, as negative } \\
\text { return of investment at }-7.9 \% \text { was } \\
\text { observed in ICRISAT study (Rao } \\
\text { et al., 2013). }\end{array}$ \\
$\begin{array}{lll}\text { 2. DCU established and } \\
\text { managed by the centralized }\end{array}$ & $\begin{array}{l}\text { As the distillery cannot be run } \\
\text { beyond } 4 \text { mo, it may establish }\end{array}$ & $\begin{array}{l}\text { All the DCUs will produce syrup } \\
\text { consistently to feed the distillery. }\end{array}$
\end{tabular}
unit (CU)

3. DCU as an alternative for crushing unit of distillery outsourced to jaggery units

4. DCU as a franchising miniethanol manufacturing unit

5. DCU supplying syrup to alternative markets (food, ready-to-serve [RTS], confectionery, vinegar) multiple DCUs and store the syrup to operate for the rest of the year.

Crushing and syrup making is outsourced to local jaggery (traditional noncentrifugal cane sugar consumed in Asia and Africa) units and procured from them.

The sweet sorghum growers were organized into an association that functions as a united entity for crop cultivation, marketing, and management of DCU. Licensing mechanism may not be permitted in some countries. Setting up of processing units in micro, small, and medium levels for food, RTS, vinegar, and confectionary production.
A viable option for the success of the DCU and CU.

Viable and useful at the village level with the miniprocessing plant. Easy management for the distillery and enhanced benefits to entrepreneurs.

Micro-, small-, and mediumlevel entrepreneurs will benefit by manufacturing nonethanol products.

Operating the DCU as a simple crushing unit and selling the syrup is one option, while outsourcing the crushing to other jaggery units might be considered to offset costs. Whichever option is selected, the distillery carries out the fermentation and distillation process to produce ethanol (Karuppanchetty and Selvaraj, 2013).

\section{Sustainability}

It is a well-known fact that many nations are facilitating biofuel production in a way that it must not compete with grain over land, it must not compete with food that population demands, it must not compete with feed for livestock, and it must not inflict harm on the environment, which are cornerstones of sustainability.

\section{Environmental Assessment}

End users are increasingly demanding sustainability and emissions accounting of sourced biomass used for biofuel production (Lal et al., 2015). In this backdrop, greenhouse gas (GHG) emissions and land-use change impacts are gaining traction as instruments for ensuring sustainability of bioenergy products and processes. This subsection briefly outlines environmental sustainability and associated complexities pertaining to sorghum-based biofuel production. The reduction of GHG emissions, like $\mathrm{CO}_{2}, \mathrm{CH}_{4}, \mathrm{~N}_{2} \mathrm{O}$ in land-use changes in terms of the use of grasslands or forests for biofuel feedstock production, is a critical factor in evaluating the agroenvironmental impact. Sorghum biomass as second-generation feedstock have a greater potential for positive environmental outcomes relative to sweet sorghum sugar or starch-based first-generation biofuel production. However, current production levels of second-generation biofuels are negligible. 


\section{Land Use, Land-Use Change and Carbon Storage}

Economic policies and social pressures are used to assess the land-use competition for food or feedstock production for biofuel. Any crop performs better in fertile land than in marginal lands. Energy crops like cassava (Manihot esculenta Crantz), Jatropha L., and sweet sorghum can grow on marginal lands. Under better management practices, the sweet sorghum cultivation results in higher $C$ stocks and a competition for food production. Thus, cultivation of sweet sorghum in the rainfed areas can provide food and income to farmers while they use their marginal land for bioethanol production (Basavaraj et al., 2013). In the last decade, the grain sorghum area cultivated during the rainy season in Maharashtra, India, has declined, as farmers chose to grow sugarcane. One positive example out of the limited contradictory studies on land-use change is that a study undertaken by the Interdisciplinary Center for Energy Planning, at the University of Campinas, São Paulo, concluded that Brazil could supply ethanol to substitute 5 and even $10 \%$ of its projected global gasoline use by 2025 without negatively affecting either the environment or food production (de Cerqueria Leite et al., 2009). Unfortunately, these kind of studies are not available for many countries. One has to mention, however, that using abandoned or marginal lands for bioenergy would avoid food impacts but not necessarily avoid the negative $\mathrm{C}$ impacts at times.

\section{Biological Diversity and Soil Quality}

The diversity in the agricultural system and the income security of small-scale farmers can be flourished by introducing sorghum in the existing cropping systems. Sorghum is pliable for various cropping systems: mono-, double, sequential, relay, strip, and intercropping or cultivation in fallow lands and crop ratooning. However, monocropping of sorghum, rather than integrating into existing diversified agricultural systems, may possibly lead to a loss of biodiversity and could be detrimental to ecosystems (Köppen et al., 2009). Further, in double cropping the input demands and the crop cycle is reduced, which might lead to lower agrobiodiversity. Whereas, by intercropping and crop rotation, eventual dwindling of the soil organic matter, and thus soil fertility, can be controlled. Integrated pest management, no-till, organic methods, and a general reduction of chemical inputs increase the agrobiodiversity of sorghum. This makes sweet sorghum cultivation more sustainable than other ethanol energy crop cultivation (Aziz et al., 2013). In tropical countries, sweet sorghum ratoons are harvested (Schaffert, 2007), reducing the need for field preparation and double use of machinery as crops other than sweet sorghum require. Hence, the nonsorghum cropping system has a higher impact on soil nutrient composition and soil erosion. Though frequent field work is essential for sorghum, as a dryland resilient crop, optimum soil conditioning with good arability helps to absorb the rain or irrigation water.

\section{Greenhouse Gas and Other Emissions}

Bioethanol production from sweet sorghum will alleviate the pressure on the use of the fossil fuel reserve and reduce the emission of GHGs in a standard scenario as explained by Köppen et al. (2009). All three products of sweet sorghum, grains, juice, and bagasse, are used for power generation (Fig. 4). Nevertheless, changes in cultivation practices, in general, to zero tillage, over intense mechanization and a shift to organic farming would further reduce the GHG emissions. The use of sweet sorghum juice from a hectare of crop, can save up to $2300 \mathrm{~L}$ of 


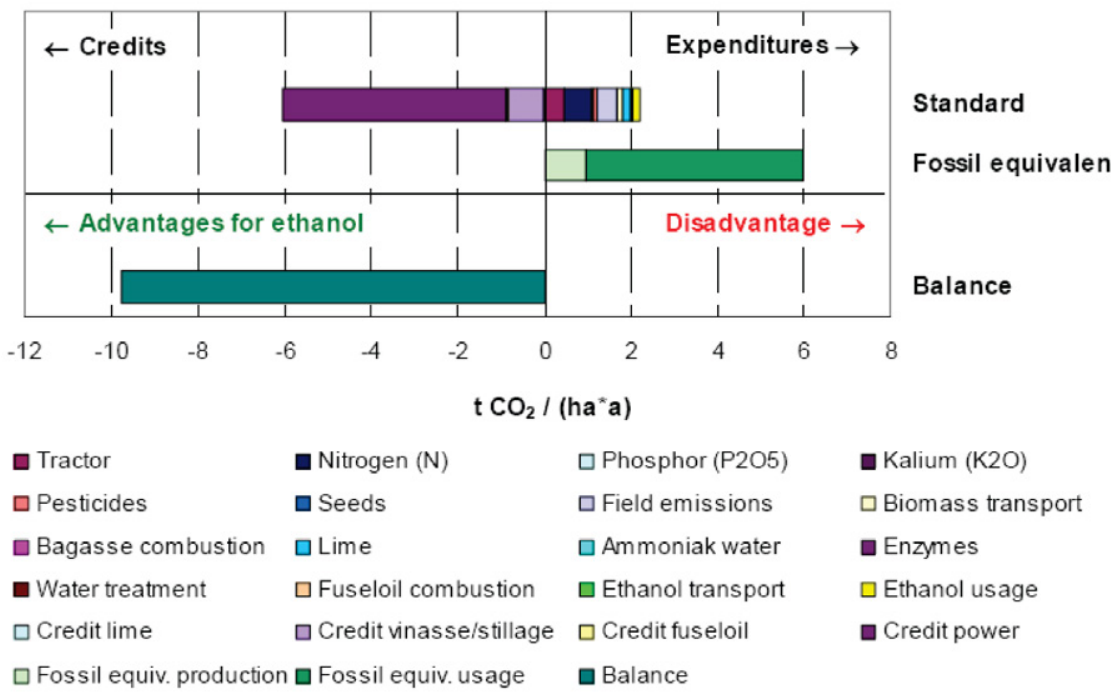

Fig. 4. Detailed greenhouse gas balance for the standard scenario as explained by Köppen et al. (2009).

crude oil and reduce GHG emissions by 1.4 to $22 \mathrm{~kg}$ of $\mathrm{CO}_{2}$ (Köppen et al., 2014). Under the circumstances where the grain is used as food and in syrup production, the remaining bagasse can be used for power generation to compensate the GHG production. Cultivars of sweet sorghum with higher fermentable sugar and juice yield can be used more efficiently to produce ethanol when compared with corn and grain sorghum ethanol. A shift to biomass as a source for production of biofuel, as promoted by many countries, is to frontier the emission of GHG (Gerbens-Leenes et al., 2009). In comparison with the other feedstocks, like corn, the use of sweet sorghum has more competitiveness, though the gains are small in terms of agronomic and environmental benefits. Furthermore, the production of green electricity rather than biofuel from sweet sorghum bagasse is more advantageous.

\section{Water Use Efficiency, Quality, and Footprint}

Sorghum offers several advantages over traditional biofuel feedstocks, such as corn, owing to its lower input requirements for water and $\mathrm{N}$ fertilizers, its ability to withstand arid and drought-like environments, and its capability to grow in marginal conditions (Köppen et al., 2009). Furthermore, sorghum has an annual growth cycle, which is attractive for cultivators who are averse to long-term commitments in perennial feedstocks like energy grasses (Dweikat et al., 2012). The water requirements of biofuel production depend on the type of feedstock used and on geographic and climatic variables. These factors must be considered to determine water footprint and to identify critical scenarios as well as mitigation strategies. In India, sugarcane is mainly cultivated under irrigation, unlike Brazil, where rainfed sugarcane is in vogue, while sweet sorghum and energy sorghum are grown largely in rainfed conditions in most of the countries. The mechanism of better water use efficiency to convert unit amount of water to biomass 
has attributed to its drought-resistant and hardy characteristics. This will in turn lead to a lower water footprint for the production of bioethanol from sorghum than from sugarcane or corn. Compared to sugarcane, sweet sorghum consumes only one-third the amount of water, thus it is more suitable under rained and semiarid conditions. Sweet sorghum consumes around 1000-1500 L of water per crop cycle based on the water footprint studies of various feedstock and production pathways for biofuel, compared with sugarcane, switchgrass (Panicum virgatum L.), wheat (Triticum aestivum L.) straw, or corn under irrigated conditions (Wu et al., 2014; Fig. 5). Differences in the water footprint were observed between locations as a consequence of climatic variables even though the feedstock was common across regions. In the case of sweet sorghum, the blue water required to produce a liter of biofuel is $1000 \mathrm{~L}$, which is five times less than that of sugarcane (Wu et al., 2014). The purpose of the crop does not decide the water footprint whether used for consumption or for energy production. A rice (Oryza sativa L.) crop has a lower water footprint in producing a unit amount of ethanol, biodiesel, or electricity than energy-dedicated crops like rapeseed (Brassica napus L.) or Jatropha. The principal debate as to whether food crops can be used for energy or not should be extended to a discussion about whether limited water resources are dedicated for food or for energy production (Roy et al., 2012).

\section{Life Cycle Assessments and Emissions Impact}

Life cycle assessments (LCAs) can be used to evaluate potential environmental impacts of biofuel production, resource levels, and public health. The LCA for energy ratio and emissions, resource level efficiency, and delineating public health impact can include all stages from feedstock production until the use of biofuel by the final consumer. This method determines the environmental suitability of a crop and associated emissions. The assessment for production of bioethanol from sweet sorghum stem juice in China revealed that energy efficiency and environmental performance show a positive net energy ratio of 1.56 and $8.37 \mathrm{MJ} \mathrm{L}^{-1}$ as the net energy gain from the production of biomass to its conversion to fuel (Wang et al., 2014b). If ethanol from sorghum is used supplemental to fossil fuels or completely substituted, $10 \mathrm{tha}^{-1} \mathrm{yr}^{-1}$ of $\mathrm{CO}_{2}$ equivalents of GHG

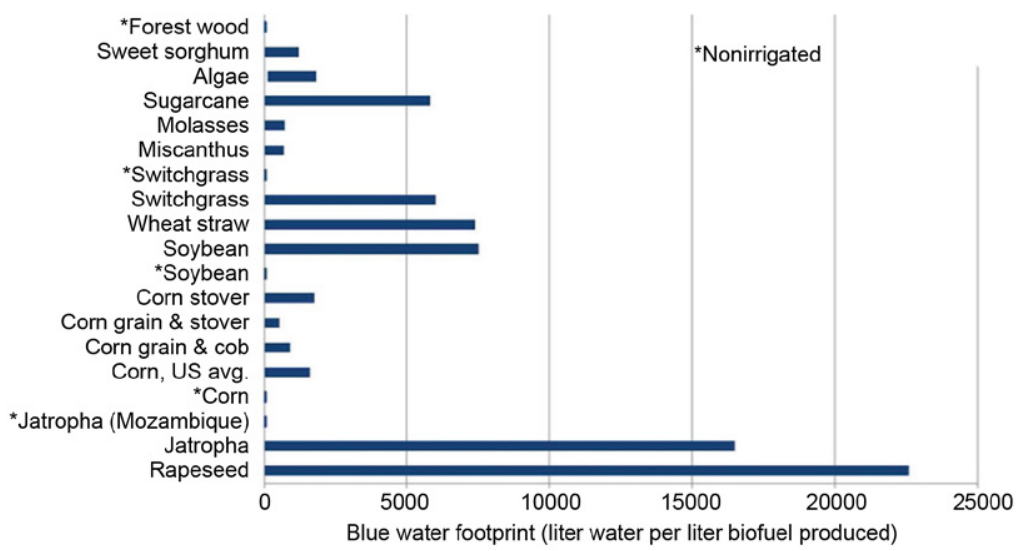

Fig. 5. Blue water foot print of various crops under irrigated and nonirrigated conditions (Wu et al., 2014). 
can be saved. The GHG savings can be primarily attributed to high biomass yields and better cultivation practices with improved high-yielding varieties or hybrids. The fermentable sugars and juice yield is not highly influential.

\section{Social Assessment}

\section{Tenures of Land for Bioenergy Production}

The land tenure will be a criterion to check in a nation where land use is very well defined. Competition for fertile lands and increased productivity can be a major issue in the future as a result of the higher demand of biofuel feedstock production as farmers and smallholders tend to shift toward more remunerative options. Even if the cultivation of the energy crops are undertaken in low, marginal, or degraded lands, there is a risk that expansion of energy feedstocks may adversely impact smallholders and lease farmers. The social impact of the large-scale biofuel cultivation in developing countries and its impact on rural livelihoods has not been systematically studied. Shifting from an extensive to an intensive production system that requires highly specialized techniques leads to a technological migration that can adversely impact land occupancy patterns. The migration of small and medium farmers by abandoning agriculture and livestock or leasing out their fertile lands for sugarcane cultivation to biofuel has caused a rise in land prices in developing countries. Hence, sound land tenure policies, planning, and policy interventions will be crucial for future expansion of the bioenergy crops especially in the developing world (Janssen and Rutz, 2011).

\section{Jobs in Bioenergy Sector and Change in Employment Impacts}

Over the past decade, the growth of the bioenergy industry has garnered the interest of both public and private sectors, owing to its potential to spur economic activity, create jobs and enhance energy security through reduced dependence on imported fossil fuels, and the possibility of limiting environmental impacts (Lal et al., 2015). From an economic perspective, sorghum-based biofuels offer the potential to supplement a country's energy needs and reduce dependence on fossil fuel imports. Akin to other biofuel feedstocks, cultivation of sorghum is likely to create on-farm employment in rural regions. For example, the South African Biofuels Association aims to foster sustainable income generating opportunities, especially for the marginalized sections of society, through the promotion of its biofuel program (Southern African Biofuels Association, 2007). The rural economies can benefit by generating employment in the agriculture sector and by sharing improved technical knowledge on crop cultivation. Local impact can be improved by developing models such as this integrated food-energy system (Aziz et al., 2013).

Brazil as an example of a successful program, which is characterized by sustainability in the production system by using local renewable raw input while, in turn, enhancing rural employment prospects. Ethanol has environment-friendly characteristics over gasoline, and the production of sugarcane-derived ethanol provides a rural development benefit. The employment opportunities created by the bioenergy sector in developing countries, like India, are expected to be significant by the year 2020, generating $~ 838,780$ jobs (Table 5). The deployment of bioenergy not only has the potential for the job creation but also industrial competitiveness, local development, and a resilient export industry (Domac et al., 2005). 
Table 5. Global employment generation from different energy production units: A prediction model adopted from Domac et al. (2005).

\begin{tabular}{lrrr}
\multicolumn{1}{c}{ Year } & 2005 & 2010 & \multicolumn{1}{c}{2020} \\
\hline Solar thermal heat & 4,590 & 7,390 & 14,311 \\
Photovoltaics & 479 & $-1,769$ & 10,231 \\
Solar thermal electric & 593 & 649 & 621 \\
Wind onshore & 8,690 & 20,822 & 35,211 \\
Wind offshore & 530 & $-7,968$ & $-6,584$ \\
Small hydro & $-11,391$ & -995 & 7,977 \\
Bioenergy & 449,928 & 642,683 & 838,780 \\
Total & 453,418 & 660,812 & 900,546 \\
\hline
\end{tabular}

\section{Bioenergy: Access to Modern Energy Services}

Modern energy services are very essential constituents in policy-making decisions. Access to modern services is equally important in developing world context such as cooking, lighting, and transportation services. The lack of modern energy services in India, where 364 million people have no provision for electricity and 726 million people use traditional open-flame methods for cooking and heating, is an indicator of policy failure (Balachandra, 2011). The agricultural activities such as tilling, irrigation, and postharvest processing demand huge amounts of energy primarily met by human labor. The rural industry also has energy requirement for milling and processing the products. The agriculture feedstock-based energy production can meet the local demand from households such as cooking, lighting, and heating. Biofuel production could also increase access to energy services with positive effects on human welfare by expanding access to electricity and pumped potable water, improving health by reducing air pollution, and improving conditions of women and children in the developing world by weaning them away from wood fuel or charcoal-based energy production. Bioenergy, such as produced from sorghum, is more advantageous and provides tremendous opportunities to develop and access these modern services (Ejigu, 2008).

\section{Economic Assessment}

\section{Economic Sustainability of Biomass and Productivity}

Food and energy security demonstrated by sweet sorghum has been mentioned in earlier sections; it is also important to note that with the existing conversion technologies, the crop fits well in the biofuel production cycle with little modifications of machinery for crushing and processing. Further value-added products can also be produced with minimum inputs. The crop can be adjusted into any of the cropping system because of the availability of genotypes with different maturity period. The mechanization of sorghum in cultivation and postharvest handling of biomass and grains can be adapted to a greater extent, though affordability and availability of machinery are a constraint. In the Philippines provinces of Bukidnon (Mindanao), Tarlac, and Pampanga (Luzon, Philippines), large tracts of land that are suitable for producing sweet sorghum are available, thus distilleries around these areas are exploring the possibility of using sweet sorghum as a complementary feedstock (Belum et al., 2011).

Above all, the biomass productivity and conversion unit sustainability depends on financial returns from ethanol prices. The demand management of ethanol includes decisions to cap ethanol supply on considerations of fairness in 
distribution of ethanol to accommodate the needs of other sectors (potable and industrial). It was also recommended by the policymakers that the size of the ethanol blending program should be linked to the availability of feedstocks (Government of India, 2009; Basavaraj et al., 2012). Lower availability of molasses, and consequently higher prices in countries like India, has also affected the cost of ethanol production, putting ethanol blending programs at stake. Hence, sorghum can be chosen as the best alternative feedstock for biofuel production. Despite several advantages of sweet sorghum as a promising alternative crop for bioethanol production, national policies in developing nations on biofuel do not specify any clear road map for its commercialization and use (Basavaraj et al., 2013).

\section{Profitability and Efficiency}

Sorghum has a high net energy balance, and although the ethanol yield per unit weight of feedstock is lower for sweet sorghum than for sugarcane, the lower production costs and water requirement for this crop compensate the yield gap. Hence, sweet sorghum still ends up with a competitive cost advantage in the production of ethanol in countries like India (Rao et al., 2004). Either the price of the main product (grain or biomass) or the by-product (fuel, fusel oil, butanol, or any other product in the value chain) will decide the choice of the crop and the end product to be produced. Alternative uses of the feedstock play a key role in the decision-making process of farmers. If the price of fuel is lower than the other end products, the choice will be to not extract biofuel from the crop. Thus, longterm viability can be achieved from a biofuel system only if the profitability is enhanced by higher efficiency as is required for advanced biofuel system like lignocellulosic biofuel production.

\section{Economic Equity and Net Energy Balance}

Sorghum can be cultivated with very low financial resources. Farmers need agricultural land and seeds to grow the crop. The plant can easily be propagated by seed. However, good productivity and efficiency of the cultivation needs input such as human work, energy, fertilizers, and pesticides. Even if the feedstock production can be done at very low cost, considerable financial resources are needed for the further processing steps such as transport, milling, and conversion to ethanol. In general, it can be said that the larger the system is the larger the financial resources required. However, the availability of financial resources is often a key limiting factor especially in developing countries.

For instance, under the grain-to-food scenario, the value of grain significantly reduces the cost of ethanol production after due credit is given to grain value. With the ongoing debate on food vs. fuel, sweet sorghum as a feedstock is found to be economically promising when the grain is used for food and stalk is used for ethanol. Ethanol production using the syrup route is the most uneconomical, while biofuel production from the stalk-only scenario is competitive under the high case. For the syrup route, the extraction of syrup at village level is still not commercially viable, adding to the overall cost of production. In all cases, feedstock costs are the major contributor to the variable production costs of ethanol followed by processing costs, labor, maintenance, and operational costs (Fig. 6). Feedstock costs, however, tend to come down as we move from the low to high case. Ethanol production under the grain-to-food scenario is competitive in all cases (Reinhardt and Cornelius, 2014). 

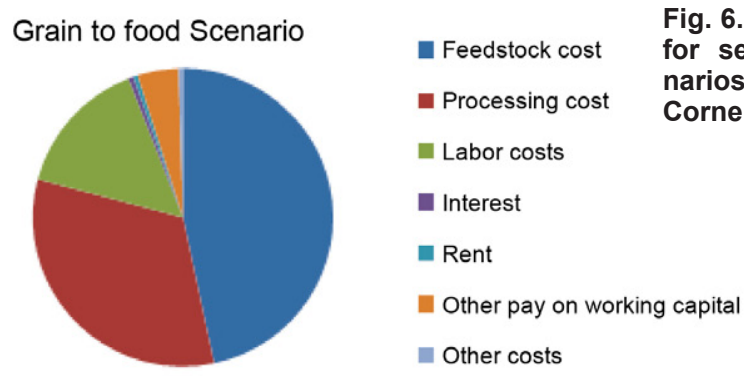

Feedstock cost

- Processing cost

- Labor costs

Interest

nent

Other pay on working capital

- Other costs

Fig. 6. Breakup of operational costs

for selected sweet sorghum scenarios (typical case) (Reinhardt and

\title{
Cane Fallow Stalk to Ethanol Scenario
}

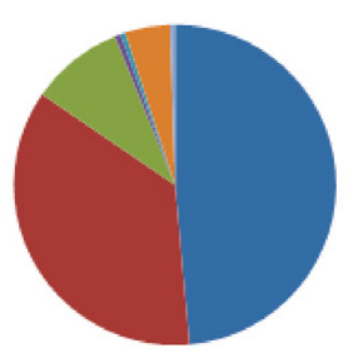

Feedstock cost

- Processing cost

- Labor costs

Interest

Rent

Other pay on working capital

Other costs

\section{Syrup to Ethanol Scenario}

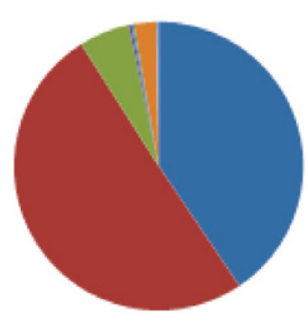

\author{
- Feedstock cost \\ - Processing cost \\ - Labor costs \\ Interest \\ Rent \\ Other pay on working capital \\ Other costs
}

\section{Competition with Food Crops}

In comparison with current sugar and starch crops for bioethanol production, sorghum offers important benefits with respect to food security, as it can serve as a multiple-purpose crop used for food, feed, and fuel at the same time. Its seeds are valuable cereals and the leaves are high-value feed, thus contributing significantly to enhancing food supply and improving food security especially in rural areas of developing countries that are prone to food insecurity. In addition to the grain used for human or animal consumption, sweet sorghum accumulates sugars with little competition between grain and sugar production. The bagasse can be used as animal feed and it is reported to have a better nutritional value than the bagasse of sugarcane (Almodares and Hadi, 2009). The production of bioethanol based on traditional food crops may lead to increases of agricultural commodity prices, which negatively affects access to food particularly in net-food importing developing countries and for the poorest therein. Significant price increases have already occurred in major bioethanol feedstock markets such as corn and sugar. Thus, the food vs. fuel conflict can be resolved by framing and implementing 
proper policies that introduce sustainability criteria, standards, and best management practices. Overall, competition with food is a potentially significant concern when investing in biofuel. The issue is not entirely resolved with second-generation biofuel even if they use nonfood feedstock because of indirect land-use changes and because of the potentially huge market demand for renewable energy in comparison with agriculture. Regulatory approaches that include procedural rules, legislatively prescribed practices, reporting, monitoring, compliance, and enforcement (Ellefson et al., 2004; Lal et al., 2013) could contribute to mitigating this potential fuel vs. food conflict.

\section{Economic Viability Assessments}

The economic and financial viability analysis has shown that feasibility of ethanol production from sweet sorghum stalk depends on the ethanol and feedstock pricing in addition to the recovery rate of ethanol. As an illustration, with a marginal improvement in recovery to $4.9 \%$ from the current level of $4.5 \%$, and feedstock price fixed in 2012 was at US $\$ 20 \mathrm{t}^{-1}$ of stalk, ethanol production became attractive at 50 cents $\mathrm{L}^{-1}$ when the administered price of ethanol in India was 48 cents $\mathrm{L}^{-}$(Basavaraj et al., 2012). The sweet-sorghum-to-ethanol scenarios, though positive, throws up mixed results. Stalk plus grain-to-ethanol (cane fallow 2020) and grain-to-food scenarios are economically most viable compared with stalk-onlyto-ethanol scenario. For the stalk-plus-grain scenario, internal rates of return (IRR) of 70 and $148 \%$ are obtained under the typical (35 $\left.\mathrm{t} \mathrm{ha}^{-1}\right)$ and high productivity $\left(>50 \mathrm{t} \mathrm{ha}^{-1}\right)$ scenarios, respectively. For the grain-to-food scenario, the IRRs are marginally lower under the typical and high cases. The stalk-only-to-ethanol scenario (cane fallow) is viable only under the high case with IRR of $25 \%$. The syrup route to ethanol is the most unviable scenario, where syrup is produced at the village level and transported to the distillery for conversion to ethanol. This is because the syrup production at village level is small scale, leading to higher costs of production. By-products generated during crop production and processing stages make an important contribution to economic returns. Among the by-products from sweet sorghum processing for ethanol, the value of surplus bagasse used to generate electricity is the highest followed by excess power, calcium carbonate, and vinasse. For biomass sorghum to biogas the return on investment is positive with IRRs of 24,44 , and 57\% under the three cases (low, typical, and high, respectively). Economic feasibility analysis of producing second-generation ethanol from sorghum biomass indicates that processing costs of second-generation ethanol determines its profitability, which in turn, depends on the enzyme price. Bringing down the enzyme price holds the key for the economic viability of second-generation ethanol (http://www.sweetfuel-project.eu/ exploitable_results).

\section{Initiatives on Bioenergy Sustainability: An Approach for Long-Term Viability}

In recent years, intensive work has been done to develop alternative sources for fossil fuels. Bioenergy is one of the most promising solutions to the depleting fossil fuel reserves on the globe. A multitude of crops and technologies were studied for efficient biofuel production, providing an established model system for adoption and commercialization. While bioenergy is being accepted and the 
most investigated alternative to fossil fuel, sustainability is an essential requirement for biofuel long-term viability. With the growing adoption and introduction of new crops and technologies, it is imperative to evaluate environmental and socioeconomic impacts. While sorghum is used as a fuel source in industry, it also ranks poorly against fossil fuels in comparison with many other biofuels because of issues such as acidification, eutrophication, photochemical smog, and ozone depletion (Elbehri et al., 2013; Regassa and Wortmann, 2014). Numerous bioenergy sustainability initiatives have been developed over the past few years to address such issues associated with the production of biofuels, which includes regulatory frameworks, voluntary standards, certification schemes, and scorecards (Fig. 7). The value chain embracing these indicators would be ideal for maximizing the socioeconomic and environmental benefits to the regions of operation but specifically to poor small holders and marginal farmers (land holding of $<2$ ha).

Some sorghum-based bioenergy initiatives were taken up in India (Rusni Distilleries, Tata Chemicals Ltd), China (ZTE Ltd, Jilin Biofuel Ltd), Philippines (Sancarlos Bioenergy Inc., Ecofuels Ltd), Brazil (Embrapa and multinational seed companies working with sugar mills), Columbia (CLAYUCA), and the United States (Southeastern Biofuel Ltd, Chromatin Ltd, BioDimensions Inc., Ceres Energy Inc., etc.). Recently, some other countries, such as Mexico, Indonesia, Mali, Mozambique, South Africa, and Australia, are investing in sweet sorghum research and development. In India, both the initiatives stopped operation for lack of policy support and other concerns related to harvesting and crushing. Other areas of priority are (i) integration of the fermentation and distillation of sweet sorghum juice in corn ethanol plants, (ii) promotion of sweet sorghum as a bioethanol feedstock in existing sugar mills having a distillery, and (iii) lignocellulosic biofuel production from energy sorghum in the recently commercialized biofuel plants, which are dependent mostly on corn stover and agricultural residues.

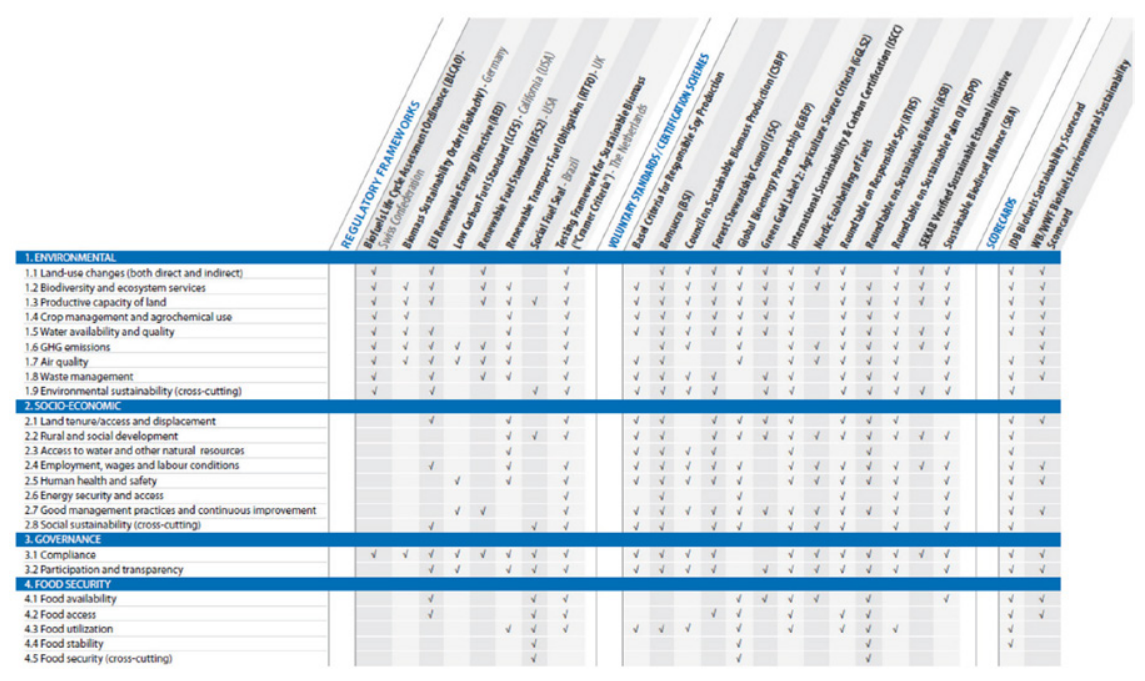

Fig. 7. Bioenergy sustainability initiatives addressing environmental, socioeconomic, governance, and food security aspects or issues (FAO, 2011). 


\section{Epilogue}

Sorghum grows better than many other crops in marginal and arid climates and produces grain, food, feed, fodder, and biofuel, which makes sorghum the crop of crops as a climate-change-ready option enhancing global food, feed, fodder, and biofuel security potential. It also provides economic stability to farmers by diversifying and channelizing the use of various value-added end products from a single crop. It complies with various biotic and abiotic stress-prone marginal lands and is also a highly reliable crop that grows well in hot, dry environments. Hence, to meet the large-scale biofuel cultivation demand and supply the raw material required for industry the research and development, oriented activities have to be promoted. Development of genotypes suitable for different agroclimatic situations, biotic and abiotic stress tolerances, and photoperiod insensitivities (to make available the biomass during off season in sugarcane cultivating areas), are of prime importance. Optimization of processing technologies for biofuel production will play a key role in reducing input cost and maximizing the benefit with diversified end products. Transitioning sweet sorghum to a bioenergy crop is hindered by lack of technology for large-scale harvest, transport, and storage of the large quantities of biomass and juice produced in addition to in-stalk fermentation as a result of delayed crushing in the tropics. Generating ethanol from lignocellulosic material or energy sorghum through hydrolysis and fermentation has the potential to give very encouraging bioenergy yields in relation to the required fossil energy inputs, but the technology has yet to be fully deployed commercially. The policy support to farmers and processors from respective governments based on regional facts (feedstock production and supply costs, processing, and ethanol handling costs) has to be developed and implemented to derive advantageous biofuel production from a multipurpose crop like sorghum.

\section{Acknowledgments}

The authors acknowledge the financial support received from the Department of Biotechnology (DBT), Government of India through Indo-US Joint Clean Energy Development Centre (JCERDC) and development of low-lignin high-biomass sorghums suitable for biofuel production.

\section{References}

Almodares, A., and M.R. Hadi. 2009. Production of bioethanol from sweet sorghum: A review. Afr. J. Agric. Res. 4:772-780.

Almodares, A., R. Taheri, M. Chung, and M. Fathi. 2008. The effect of nitrogen and potassium fertilizers on growth parameters and carbohydrate contents of sweet sorghum cultivars. J. Environ. Biol. 29:849-852.

Antonopoulou, G., H. Gavala, I. Skiadas, K. Angelopoulos, and G. Lyberatos. 2008. Biofuels generation from sweet sorghum: Fermentative hydrogen production and anaerobic digestion of the remaining biomass. Bioresour. Technol. 99:110-119. doi:10.1016/j. biortech.2006.11.048

Ashori, A. 2008. Wood-plastic composites as promising green-composites for automotive industries. Bioresour. Technol. 99:4661-4667. doi:10.1016/j.biortech.2007.09.043

Aziz, I., T. Mahmood, and K.R. Islam. 2013. Effect of long term no-till and conventional tillage practices on soil quality. Soil Tillage Res. 131:28-35. doi:10.1016/j.still.2013.03.002

Balachandra, P. 2011. Modern energy access to all in rural India: An integrated implementation strategy. Energy Policy 39:7803-7814. doi:10.1016/j.enpol.2011.09.026 
Basavaraj, G., P.P. Rao, C. Ravinder Reddy, A. Ashok Kumar, P. Srinivasa Rao, and B.V.S. Reddy. 2012. A review of the National Biofuel Policy in India: A critique of the need to promote alternative feedstocks. J. Biofuels 3:65-78. doi:10.5958/j.0976-4763.3.2.007

Basavaraj, G., P.P. Rao, L. Achoth, and C.R. Reddy. 2013. Assessing competitiveness of sweet sorghum for ethanol production: A policy analysis matrix approach. Agric. Econ. Res. Rev. 26:31-40.

Belayachi, L. and M. Delmas. 1995. Sweet Sorghum: A quality raw material for the manufacturing of chemical paper pulp. Biomass Bioenergy 8:411-417. doi:10.1016/0961-9534(95)00046-1

Bello, A.B., L.W. Rooney, and R.D. Waniska. 1990. Factors affecting quality of sorghum to a thick porridge. Cereal Chem. 67:20-25.

Belum, V.S.R., A.A. Kumar, C.R. Reddy, P.P. Rao, and J.V. Patil, editors. 2013. Developing a sweet sorghum ethanol value chain. Patancheru 502 324. International Crops Research Institute for the Semi-Arid Tropics, Andhra Pradesh, India.

Belum, V.S.R., H. Layaoen, W.D. Dar, P. Srinivasarao, and J.E. Eusebio, editors. 2011. Sweet sorghum in the Philippines: Status and future. ICRISAT, Patancheru, Andhra Pradesh, India.

Bout, S., and W. Vermerris. 2003. A candidate-gene approach to clone the sorghum Brown midrib gene encoding caffeic acid O-methyltranseferase. Mol. Genet. Genomics 269:205-214. doi:10.1007/s00438-003-0824-4

Bridgers, E.N., M.S. Chinn, M.W. Veal, and L.F. Stikeleather. 2011. Influence of juice preparations on the fermentability of sweet sorghum. Biol. Eng. Trans. 4:57-67. doi:10.13031/2013.38507

Brown, P.J., W.L. Rooney, C. Franks, and S. Kresovich. 2008. Efficient mapping of plant height quantitative trait loci in a sorghum association population with introgressed dwarfing genes. Genetics 180:629-637. doi:10.1534/genetics.108.092239

Chakraborty, S.K., D.S. Singh, B. Kumbhar, and S. Chakraborty. 2011. Process optimization with respect to the expansion ratios of millet- and legume (pigeon pea)-based extruded snacks. J. Food Process Eng. 34:777-791. doi:10.1111/j.1745-4530.2009.00433.x

Cheng, Y., S. Li, J. Huang, Q. Zhang, and X. Wang. 2008. Production of acetone and butanol by fermentation of sweet sorghum stalks juice. Trans. Chin. Soc. Agric. Eng. 24:177-180.

Cifuentes, R., R. Bressani, and C. Rolz. 2014. The potential of sweet sorghum: As a source of ethanol and protein. Energy Sustainable Dev. 21:13-19. doi:10.1016/j.esd.2014.04.002

Cutz, L., S. Sanchez-Delgado, U. Ruiz-Rivas, and D. Santana. 2013. Bioenergy production in Central America: Integration of sugar mills. Renew. Sustain. Energy Rev. 25:529-542. doi:10.1016/j.rser.2013.05.007

de Cerqueria Leite, R.C., M.R.L.V. Leal, L.A.B. Cortez, W.M. Griffin, and M.I.G. Scandiffio. 2009. Can Brazil replace 5\% of the 2025 gasoline world demand with ethanol? Energy 34:655-661. doi:10.1016/j.energy.2008.11.001

Domac, J., K. Richards, and S. Risovic. 2005. Socio-economic drivers in implementing bioenergy projects. Biomass Bioenergy 28:97-106. doi:10.1016/j.biombioe.2004.08.002

Dweikat, I., C. Weil, S. Moose, L. Kochian, N. Mosier, K. Ileleji, and N. Carpita. 2012. Envisioning the transition to a next-generation biofuels industry in the US Midwest. Biofuels, Bioprod. Biorefin. 6:376-386. doi:10.1002/bbb.1342

Economou, C.N., A. Makri, G. Aggelis, S. Pavlou, and D.V. Vayenas. 2010. Semi-solid state fermentation of sweet sorghum for the biotechnological production of single cell oil. Bioresour. Technol. 101:1385-1388. doi:10.1016/j.biortech.2009.09.028

Ejigu, M. 2008. Toward energy and livelihoods security in Africa: Smallholder production and processing of bioenergy as a strategy. Nat. Resour. Forum 32:152-162 doi:10.1111/j.1477-8947.2008.00189.x

Elbehri, A., A. Segerstedt, and L. Pascal. 2013. Biofuels and the sustainability challenge: A global assessment of sustainability issues, trends and policies for biofuels and related feedstocks, Trade and markets division, Food and Agriculture Organization of the United Nations, Rome.

Ellefson, P.V., M.A. Kilgore, C.M. Hibbard, and J.E. Granskog. 2004. Regulation of forestry practices on private land in the United States: Assessment of state agency 
responsibilities and program effectiveness (No. 176). Dep. of Forest Resources, Univ. of Minnesota, St. Paul.

FAO. 2011. A compilation of bioenergy sustainability initiatives. Bioenergy and Food Security, Food and Agriculture Organization of the United Nations. http://www.fao.org/ bioenergy/foodsecurity/befsci/62379/en (accessed 1 Feb. 2016).

Faparusi, S. 1970. Sugar changes during the preparation of Burukutu beer. J. Sci. Food Agric. 21:79-81. doi:10.1002/jsfa.2740210206

Gao, C., Y. Zhai, Y. Ding, and Q. Wu. 2010. Application of sweet sorghum for biodiesel production by heterotrophic microalga Chlorella protothecoides. Appl. Energy 87:756-761. doi:10.1016/j.apenergy.2009.09.006

Gerbens-Leenes, W., A.Y. Hoekstra, and T.H. van der Meer. 2009. The water footprint of bioenergy. Proc. Natl. Acad. Sci. USA 106:10219-10223. doi:10.1073/pnas.0812619106

Giarola, S., N. Shah and F. Bezzo. 2012. A comprehensive approach to the design of ethanol supply chains including carbon trading effects. Bioresour. Technol. 107:175-185.

Glatz, B.A., E.G. Hammond, K.H. Hsu, L. Baehman, N. Bati, W. Bednarski, D. Brown and M. Floetenmeyer. 1984. Production and modification of fats and oils by yeast fermentation. In: C. Ratledge, P. Dawson, and J. Rattray, editors, Biotechnology for the oils and fats industry. American Oil Chemists' Society, Champaign, IL. p. 163-176.

Glennie, C.W., and A.W. Wight. 1986. Dextrins in sorghum beer. J. Inst. Brew. 92:384-386. doi:10.1002/j.2050-0416.1986.tb04428.x

Government of India. 2009. Report of the working group on animal husbandry and dairying for the 11th five year plan (2007-2012), Government of India, Planning Commission, Delhi. http://planningcommission.nic.in/aboutus/committee/wrkgrp11/wg11_rpanim. pdf (accessed 1 Feb. 2016).

Harlan, J.R., and J.M. de Wet. 1971. Toward a rational classification of cultivated plants. Taxon 20:509-517. doi:10.2307/1218252

Harlan, J.R., and J.M.J. de Wet. 1972. A simplified classification of cultivated sorghum. Crop Sci. 12:172-176. doi:10.2135/cropsci1972.0011183X001200020005x

Hetényi, K., K. Gál, Á. Németh, and B. Sevella. 2010. Use of sweet sorghum juice for lactic acid fermentation: Preliminary steps in a process optimization. J. Chem. Technol. Biotechnol. 85:872-877. doi:10.1002/jctb.2381

House, L.R. 1985. A guide to sorghum breeding, 2nd ed. ICRISAT, Andhra Pradesh , India.

Janssen, R., and D.D. Rutz. 2011. Sustainability of biofuels in Latin America: Risks and opportunities. Energy Policy 39:5717-5725. doi:10.1016/j.enpol.2011.01.047

Jerger, D.E., D.P. Chynoweth, and H.R. Isaacson. 1987. Anaerobic digestion of sorghum biomass. Biomass 14:99-113. doi:10.1016/0144-4565(87)90013-8

Kangama, C.O., and X. Rumei. 2005. Production of crystal sugar and alcohol from sweet sorghum. Afr. J. Food Agric. Nutr. Dev. 5:1-5.

Karuppanchetty, S.M., and A. Selvaraj. 2013. Business models for viability of sweet sorghum decentralized crushing unit. In: B.V.S. Reddy, A.A. Kumar, C.R. Reddy, P.P. Rao, and J.V. Patil, editors, Developing a sweet sorghum ethanol value chain. ICRISAT. Andhra Pradesh, India. p. 193-196.

Klimiuk, E., T. Pokój, W. Budzynski, and B. Dubis. 2010. Theoretical and observed biogas production from plant biomass of different fibre contents. Bioresour. Technol. 101:9527-9535. doi:10.1016/j.biortech.2010.06.130

Köppen, S., H. Fehrenbach, S. Markwardt, A. Hannecke, U. Eppler, and U.R. Fritsche. 2014. Final report on implementing the GBEP indicators for sustainable bioenergy in Germany. Institut für Energie- und Umweltforschung (Heidelberg) and International Institute for Sustainability Analysis and Strategy, Darmstadt, Germany.

Köppen, S., G. Reinhardt, and S. Gärtner. 2009. Assessment of energy and greenhouse gas inventories of Sweet Sorghum for first and second generation bioethanol. In FAO Environmental and Natural Resources Service Series No. 30. FAO, Rome.

Lal, P., P. Burli, and J.R.R. Alavalapati. 2015. Policy mechanisms to implement and support biomass and biofuel projects in United States. In: S. Jose and T. Bhaskar, editors, 
Biomass and biofuels: Advanced biorefineries for sustainable production and distribution. CRC Press, Boca Raton, FL. p. 279-301

Lal, P., T. Upadhyay, and J.R.R. Alavlapati. 2013. Woody biomass for bioenergy: A policy overview. In: J.M. Evans, R.J. Fletcher, J.R.R. Alavalapati, A.L. Smith, D. Geller, P. Lal, D. Vasudev, M. Acevedo, J. Calabria, and T. Upadhyay, editors, Forestry bioenergy in the Southeast United States: Implications for wildlife habitat and biodiversity. National Wildlife Federation, Merriðeld, VA. p. 248-255. http://www.nwf.org/ /media/ PDFs/Wildlife/Conservation/NWF_Biomass_Biodiversity_Final.ashx (accessed 21 Mar. 2015).

Legwaila, G.M., T.V. Balole, and S.K. Karikari. 2003. Review of sweet sorghum: A potential cash and forage crop in Botswana. UNISWA J. Agric. 12:5-14.

Li, S., G. Li, L. Zhang, Z. Zhou, B. Han, W. Hou, J. Wang, and T. Li. 2013. A demonstration study of ethanol production from sweet sorghum stems with advanced solid state fermentation technology. Appl. Energy 102:260-265. doi:10.1016/j.apenergy.2012.09.060

Liang, Y., N. Sarkany, Y. Cui, J. Yesuf, J. Trushenski, and J.W. Blackburn. 2010. Use of sweet sorghum juice for lipid production by Schizochytrium limacinum SR21. Bioresour. Technol. 101:3623-3627. doi:10.1016/j.biortech.2009.12.087

Liang, Y., T. Tang, T. Siddaramu, R. Choudhary, and A.L. Umagiliyage. 2012. Lipid production from sweet sorghum bagasse through yeast fermentation. Renew. Energy 40:130-136. doi:10.1016/j.renene.2011.09.035

Liu, L., T.J. Herald, D. Wang, J.D. Wilson, S.R. Bean, and F.M. Aramouni. 2012. Characterization of sorghum grain and evaluation of sorghum flour in a Chinese egg noodle system. J. Cereal Sci. 55:31-36. doi:10.1016/j.jcs.2011.09.007

Marx, S., B. Ndaba, I. Chiyanzu, and C. Schabort. 2014. Fuel ethanol production from sweet sorghum bagasse using microwave irradiation. Biomass Bioenergy 65:145-150. doi:10.1016/j.biombioe.2013.11.019

Matsakas, L., U. Rova, and P. Christakopoulos. 2014. Evaluation of dried sweet sorghum stalks as raw material for methane production. BioMed Res. Int. 2014:1-7. doi:10.1155/2014/731731

McKevith, B. 2004. Nutritional aspects of cereals. British Nutrition Foundation. Nutr. Bull. 29:111-142. doi:10.1111/j.1467-3010.2004.00418.x

Meng, X., J. Yang, X. Xu, L. Zhang, Q. Nie, and M. Xian. 2009. Biodiesel production from oleaginous microorganisms. Renew. Energy 34:1-5. doi:10.1016/j.renene.2008.04.014

Menon, V., and M. Rao. 2012. Trends in bioconversion of lignocellulose: Biofuels, platform chemicals and biorefinery concept. Pror. Energy Combust. Sci. 38:522-550. doi:10.1016/j. pecs.2012.02.002

Mohammed, A.A., B.R. Hamaker, and A. Aboubacar. 1993. Effects of flour-to-water ratio and time of testing on sorghum porridge firmness as determined by a uniaxial compression test. Cereal Chem. 70:739-743.

National Sweet Sorghum Producers and Processors Association. 2015. NSSPPA, Cookeville, TN. http://www.nssppa.org/Sweet_Sorghum_FAQs.html (accessed 28 Sept. 2015).

Ntaikou, I., H.N. Gavala, and G. Lyberatos. 2010. Application of a modified anaerobic digestion model 1 version for fermentative hydrogen production from sweet sorghum extract by Ruminococcus albus. Int. J. Hydrogen Energy 35:3423-3432. doi:10.1016/j. ijhydene.2010.01.118

Oliver, A.L., J.F. Pedersen, R.J. Grant and T.J. Klopfenstein. 2005. Comparative effects of the sorghum $b m r-6$ and $b m r-12$ genes: I. Forage sorghum yield and quality. Crop Sci. 45:2234-2239. doi:10.2135/cropsci2004.0660

Ostovareh, S., K. Karimi, and A. Zamani. 2015. Efficient conversion of sweet sorghum stalks to biogas and ethanol using organosolv pretreatment. Ind. Crops Prod. 66:170177. doi:10.1016/j.indcrop.2014.12.023

Packer, D.J., and W.L. Rooney. 2014. High-parent heterosis for biomass yield in photoperiodsensitive sorghum hybrids. Field Crops Res. 167:153-158. doi:10.1016/j.fcr.2014.07.015

Panagiotopoulos, I.A., R.R. Bakker, T. de Vrije, E.G. Koukios, and P.A.M. Claassen. 2010. Pretreatment of sweet sorghum bagasse for hydrogen production by Caldicellulosiruptor saccharolyticus. Int. J. Hydrogen Energy 35:7738-7747. doi:10.1016/j.ijhydene.2010.05.075 
Porter, K.S., J.D. Axtell, V.L. Lechtenberg, and V.F. Colenbrander. 1978. Phenotype, fiber composition, and in vitro dry matter disappearance of chemically induced brown midrib (bmr) mutants of sorghum. Crop Sci. 18:205-208. doi:10.2135/cropsci1978.0011183X 001800020002x

Prakasham, R.S., P. Brahmaiah, D. Nagaiah, P. Srinivasarao, B.V.S. Reddy, R. Sreenivas, and P.J. Hobbs. 2012. Impact of low lignin containing brown midrib sorghum mutants to harness biohydrogen production using mixed anaerobic consortia. Int. J. Hydrogen Energy 37:3186-3190. doi:10.1016/j.ijhydene.2011.11.082

Prakasham, R.S., D. Nagaiah, K.S. Vinutha, A. Uma, T. Chiranjeevi, A.V. Umakanth, P. Srinivasarao, and N. Yan. 2014. Sorghum biomass: A novel renewable carbon source for industrial bioproducts. Biofuels 5:159-174. doi:10.4155/bfs.13.74

Promkhambut, A., A. Younger, A. Polthanee, and C. Akkasaeng. 2010. Morphological and physiological responses of sorghum (Sorghum bicolor L. Moench) to water logging. Asian J. Plant Sci. 9:183-193. doi:10.3923/ajps.2010.183.193

Rao, B.D., C.V. Ratnavathi, K. Karthikeyan, P.K. Biswas, S.S. Rao, B.S. Vijay Kumar, and N. Seetharama. 2004. Sweet Sorghum cane for biofuel production: A SWOT analysis in Indian context. National Research Center for Sorghum, Hyderabad, Andhra Pradesh, India.

Rao, P.P., G. Basavaraj, K. Basu, C.R. Reddy, A.A. Kumar and B.V.S. Reddy. 2013. Economics of sweet sorghum feedstock production for bioethanol. In: Developing a sweet sorghum ethanol value chain. ICRISAT, Patancheru, Andhra Pradesh, India. p. 99-109.

Ratledge, C., and J.P. Wynn. 2002. The biochemistry and molecular biology of lipid accumulation in oleaginous microorganisms. Adv. Appl. Microbiol. 51:11-51.

Regassa, T.H., and C.S. Wortmann. 2014. Sweet sorghum as a bioenergy crop: Literature review. Biomass Bioenergy 64:348-355. doi:10.1016/j.biombioe.2014.03.052

Reinhardt, G., and C. Cornelius. 2014. Environmental assessment of energy sorghum. Presented at the SWEETFUEL Regional Stakeholder Workshop, Hamburg, Germany. 26 June 2014. http://www.sweetfuel-project.eu/sweetfuel_events/sweetfuel_at_the_22nd_ european_biomass_conference_exhibition (accessed 1 Feb. 2016).

Richter, K., and C. Berthold. 1998. Biotechnological conversion of sugar and starchy crops into lactic acid. J. Agric. Eng. Res. 71:181-191. doi:10.1006/jaer.1998.0314

Rooney, L.W. 1967. Properties of sorghum grain and new developments of possible significance to the brewing industry. Tech. Q. Master Brew. Assoc. Am. 6:277-282.

Roy, P., T. Orikasa, K. Tokuyasu, N. Nakamura, and T. Shiina. 2012. Evaluation of the life cycle of bioethanol produced from rice straws. Bioresour. Technol. 110:239-244. doi:10.1016/j.biortech.2012.01.094

Saballos, A., G. Ejeta, E. Sanchez, C. Kang, and W. Vermerris. 2009. A genome wide analysis of the cinnamyl alcohol dehydrogenase family in Sorghum [Sorghum bicolor (L.)Moench] identifies SbCAD2 as the brown midrib6 gene. Genetics 181:783-795. doi:10.1534/genetics.108.098996

Saballos, A., W. Vermerris, L. Rivera, and G. Ejeta. 2008. Allelic association, chemical characterization and saccharification properties of brown midrib mutants of sorghum (Sorghum bicolor (L.) Moench). Bioenerg. Res. 1:193-204. doi:10.1007/s12155-008-9025-7

Samuel, W.A., Y.Y. Lee, and W.B. Anthony. 1980. Lactic acid fermentation of crude sorghum extract. Biotechnol. Bioeng. 22:757-777. doi:10.1002/bit.260220404

Saraphirom, P., and A. Reungsang. 2010. Optimization of biohydrogen production from sweet sorghum syrup using statistical methods. Int. J. Hydrogen Energy 35:1343513444. doi:10.1016/j.ijhydene.2009.11.122

Sattler, S.E., D.L. Funnell-Harris, and J.F. Pedersen. 2010. Brown midrib mutations and their importance to the utilization of maize, sorghum, and pearl millet lignocellulosic tissues. Plant Sci. 178:229-238. doi:10.1016/j.plantsci.2010.01.001

Satyanarayana, K.G., G.G.C. Arizaga, and F. Wypych. 2009. Biodegradable composites based on lignocellulosic fibers: An overview. Prog. Polym. Sci. 34:982-1021. doi:10.1016/j. progpolymsci.2008.12.002

Schaffert, R.E. 2007. Sweet Sorghum improvement and production in Brazil. Paper presented at the Global consultation on Pro-poor sweet sorghum development for 
bioethanol production and introduction to tropical sugar beet. Rome, Italy. 8-9 Nov. 2007

Schaffert, R.E., and L.M. Gourley. 1982. Sorghum as energy source. In: Proceedings of the International Symposium on Sorghum, 2-7 Nov. 1981. ICRISAT, Patancheru, Andhra Pradesh, India. p. 605-623.

Serna-Saldivar, S.O., D.A. Knabe, L.W. Rooney, T.D. Tanksley, Jr., and A.M. Sproule. 1988. Nutritional value of sorghum and maize tortillas. J. Cereal Sci. 7:83-94. doi:10.1016/ S0733-5210(88)80062-6

Southern African Biofuels Association. 2007. Bio-ethanol from grains to increase food security? SABA, Johannesburg. http://www.ee.co.za/article/bio-ethanol-from-grainsto-increase-food-security.html (accessed 28 Sept. 2015).

Srinivasarao, P., C.G. Kumar, J. Malapaka, A. Kamal, and B.V.S. Reddy. 2012. Feasibility of sustaining sugars in sweet sorghum stalks during post-harvest stage by exploring cultivars and chemicals: A desk study. Sugar Tech. 14:21-25. doi:10.1007/s12355-011-0133-x

Srinivasarao, P., C.G. Kumar, R.S. Prakasham, A.U. Rao and B.V.S. Reddy. 2015. Sweet sorghum: Breeding and bioproducts. In: V.M.V. Cruz and D.A. Dierig, editors, Industrial crops. Springer, New York. p. 1-28.

Srinivasarao, P., C.G. Kumar, and B.V.S. Reddy. 2013. Sweet sorghum: From theory to practice. In: P.S. Rao and C.G. Kumar, editors, Characterization of improved sweet sorghum cultivars. Springer, India. p. 1-15.

Srinivasarao, P., S.S. Rao, N. Seetharama, and A.V. Umakath. P. SanjanaReddy, B.V.S. Reddy and C.L.L. Gowda. 2009. Sweet sorghum for biofuel and strategies for its improvement. Information Bulletin No. 77. ICRISAT, Patancheru, Andhra Pradesh, India.

Vietor, D.M., and F.R. Miller. 1990. Assimilation, partitioning, and nonstructural carbohydrates in sweet compared with grain sorghum. Crop Sci. 30:1109-1115. doi:10.2135/cro psci1990.0011183X003000050030x

Vinutha, K.S., L. Rayaprolu, K. Yadagiri, A.V. Umakanth, and P. Srinivasarao. 2014. Sweet sorghum research and development in India: Status and prospects. Sugar Tech. 16:133-143. doi:10.1007/s12355-014-0302-9

Wang, M., Y. Chen, X. Xia, J. Li, and J. Liu. 2014a. Energy efficiency and environmental performance of bioethanol production from sweet sorghum stem based on life cycle analysis. Bioresour. Technol. 163:74-81. doi:10.1016/j.biortech.2014.04.014

Wang, S., A. Hastings, S. Wang, G. Sunnenberg, M.J. Tallis, E. Casella, S. Taylor, P. Alexander, I. Cisowska, A. Lovett, G. Taylor, S. Firth, D. Moran, J. Morison, and P. Smith. 2014b. The potential for bioenergy crops to contribute to meeting GB heat and electricity. Global Change Biol. Bioenergy demands. 6:136-141.

Woods, J. 2000. Integrating sweet sorghum and sugarcane for bioenergy: Modelling the potential for electricity and ethanol production in SE Zimbabwe. Ph.D. thesis. King's College, London.

Wu, M., Z. Zhang, and Y.W. Chiu. 2014. Life-cycle water quantity and water quality implications of biofuels. Current Sustainable/Renewable Energy Rep. 1:3-10.

Wu, X., S. Staggenborg, J.L. Propheter, W.L. Rooney, J. Yu, and D. Wang. 2010. Features of sweet sorghum juice and their performance in ethanol fermentation. Ind. Crops Prod. 31:164-170. doi:10.1016/j.indcrop.2009.10.006

Yadav, A.K., N.K. Bipinraj, A.B. Chaudhari, and R.M. Kothari. 2011. Production of L(+) lactic acid from sweet sorghum, date palm, and golden syrup as alternative carbon sources. Starke 63:632-636. doi:10.1002/star.201100006

Zhang, T., N. Du, and T. Tan. 2011. Biobutanol production from sweet sorghum bagasse. J. Biobased Mater. Bioenergy 5:331-336. doi:10.1166/jbmb.2011.1158 